\title{
STUDI PARAMETER BURNUP SEL BAHAN BAKAR BERBASIS THORIUM NITRIDE PADA REAKTOR CEPAT BERPENDINGIN HELIUM
}

\author{
Ridha Mayanti ${ }^{1, \mathrm{a})}$, Menik Ariani ${ }^{2, \mathrm{~b})}$, Fiber Monado ${ }^{2, \mathrm{c})}$ \\ ${ }^{1}$ Program Studi Magister Fisika, Pascasarjana Universitas Sriwijaya, \\ Jl. Padang Selasa 542, Palembang, Sumatera Selatan \\ ${ }^{2}$ Jurusan Fisika FMIPA, Universitas Sriwijaya, Kampus Indralaya, Ogan Ilir, Sumatera Selatan \\ Email: a)riimayanti@gmail.com, b) menikariani@gmail.com, ${ }^{\mathrm{c}}$ fibermonado@unsri.com
}

\begin{abstract}
Abstrak
Thorium dapat dijadikan alternatif bahan bakar nuklir. Namun, karena thorium alam tidak memiliki isotop fisil maka pada tahap awal pembakaran perlu ditambahkan nuklida fisil seperti Pu-239. Penelitian ini menyajikan studi parameter hasil dari perhitungan sel bahan bakar berbasis thorium dengan atau tanpa penambahan plutonium-239. Fraksi volume sel yang digunakan yaitu $65 \%$ fuel, $10 \%$ stainless steel sebagai cladding dan 25\% helium sebagai coolant. Parameter yang dihitung adalah faktor multiplikasi efektif (keff), faktor multiplikasi infinite (kinf), rasio konversi dan perubahan densitas nuklida hasil dari reaksi fisi sepanjang waktu burnup bahan bakar. Beberapa parameter neutronik hasil perhitungan sel dapat menunjukkan pengaruh dari penambahan plutonium-239 terhadap tingkat kekritisan reaktor.
\end{abstract}

Kata-kata kunci: Sel bahan bakar, thorium, plutonium, burnup.

\begin{abstract}
Thorium can be used as an alternative nuclear fuel. However natural thorium (thorium232) has no fissile isotope, so in the early stages of burning should be added fissile nuclides such as Plutonium-239. This study presents the results of a parameter study of calculation thorium-based fuel cells with or without addition of plutonium-239. The volume fraction of cells used is $65 \%$ fuel, $10 \%$ stainless steel as a cladding and $25 \%$ helium as the coolant. Neutronic parameters calculated was the effective multiplication factor $\left(\mathrm{k}_{\mathrm{eff}}\right)$, infinite multiplication factor $\left(\mathrm{k}_{\mathrm{inf}}\right)$ and nuclide density changes as the result from the fission nuclides over time burnup fuel. Those parameters indicated the influence of plutonium-239 addition to the level of critical reactor.
\end{abstract}

Keywords: temperature distribution, LM35 sensor, DC motor, LabVIEW.

\section{PENDAHULUAN}

Energi merupakan salah satu kebutuhan yang sangat penting. Peningkatan populasi penduduk dunia merupakan salah satu faktor yang menyebabkan kebutuhan energi semakin tinggi. Peningkatan kebutuhan energi ini tidak diimbangi dengan keberadaan sumber daya energi yang sebagian besarnya masih memanfaatkan energi fossil. Saat ini, krisis energi terjadi di berbagai negara sehingga banyak negara mulai membangun rencana pengembangan energi. 
Energi yang dihasilkan dari reaksi fisi pada reaktor nuklir menjadi salah satu sumber energi alternatif yang dapat mengatasi permasalahan krisis energi. Beberapa kelebihan yang dimiliki reaktor nuklir dibandingkan dengan pembangkit energi konvensional berbasis bahan bakar fosil, yaitu reaktor nuklir memiliki daya dukung dalam mengurangi pemanasan global dan pada proses normal reaktor nuklir tidak menghasilkan emisi gas rumah kaca sehingga tidak mencemari udara. Adapun jika dibandingkan dengan sumber daya energi terbarukan, energi nuklir mampu menghasilkan daya listrik yang besar. PLTN diharapkan mampu menggantikan sumber energi berbasis energi fosil yang pasokannya akan habis.

Reaksi fisi harus berlangsung secara terkendali di dalam sebuah reaktor nuklir [1]. Pengendalian reaksi fisi yang terjadi di dalam reaktor dilakukan agar perubahan jumlah neutron dibatasi sehingga hanya satu neutron saja yang akan diserap untuk pembelahan inti berikutnya. Keadaan yang diinginkan dalam reaktor adalah keseimbangan jumlah neutron, sehingga jumlah neutron yang membentuk reaksi fisi adalah tetap.

Pada akhir tahun 2004 seluruh reaktor daya komersial yang beroperasi di seluruh dunia membutuhkan 67.320 ton uranium, sedangan produksi tambang uranium dunia adalah 40.263 ton atau sekitar $60 \%$ dari kebutuhan. Untuk menutupi kekurangan pasokan tahunan digunakan sumber sekunder berupa hasil repsrosesing bahan bakar bekas, pengayaan ulang, dan lain-lain [2, 3]. Berdasarkan data (IAEA) hingga April 2014, terdapat 435 Pembangkit Listrik Tenaga Nuklir yang beroperasi di 31 negara. Dari berbagai jenis reaktor yang telah beroperasi di dunia, sebagian besar bahan bakar yang digunakan adalah uranium-235. Dibutuhkan cadangan uranium yang cukup besar sebagai bahan bakar PLTN.

Thorium seperti halnya uranium dapat digunakan sebagai bahan bakar nuklir meskipun tidak bersifat fisil $[2,4,5]$. Dalam bahan bakar thorium, semua fisi berasal dari komponen penggeraknya misalnya ${ }^{233} \mathrm{U}$. Fisi dari ${ }^{233} \mathrm{U}$ ini menghasilkan jumlah energi yang hampir sama dengan ${ }^{235} \mathrm{U}$ yaitu sekitar \pm 168 hingga $\pm 200 \mathrm{MeV}$ [6]. Persamaan reaksi penangkapan neutron oleh thorium dinyatakan oleh [7]:

$$
\begin{aligned}
& { }_{0}^{1} n+{ }_{90}^{292} T h \rightarrow{ }_{90}^{293} T h+\gamma \\
& { }_{90}^{203} T h \rightarrow{ }_{91}^{2 a d} P a+{ }_{-1}^{0} e+v^{*}+\gamma \\
& { }_{91}^{233} \mathrm{~Pa} \rightarrow{ }_{92}^{233} U+{ }_{-1}^{0} e+v^{*}+\gamma \\
& { }_{0}^{1} n+{ }_{90}^{221} T h \rightarrow{ }_{92}^{22 a} U+2{ }_{-1}^{0} e+2 v^{*}+3 \gamma
\end{aligned}
$$

Selain uranium-233 adapun material fisil yang digunakan sebagai pemicu reaksi fisi nuklir adalah plutonium 239. Plutonium-239 merupakan material fisil, yakni material yang dapat membelah ketika dibombardir oleh neutron, melepaskan energi, radiasi gamma, dan neutron yang lebih banyak. Oleh karena itu, plutonium-239 dapat mempertahankan reaksi rantai nuklir setelah mencapai massa kritis. Sifat-sifat inilah yang memungkinkan plutonium digunakan sebagai bahan bakar pada beberapa reaktor nuklir.

Studi terkait sehubungan perancangan reaktor nuklir dengan penggunaan thorium sebagai bahan bakar telah dilakukan. Thorium alam (Th-232) dapat menghasilkan bahan fisil uranium-233 sehingga memiliki potensi sebagai bahan bakar sebuah reaktor nuklir. Pemanfaatan bahan bakar campuran uranium alam dan thorium menunjukkan performa yang baik dengan keff pada teras reaktor yang selalu diatas 1 untuk waktu burnup 10 tahun. Hal ini menunjukkan bahwa reaktor dapat beroperasi selama 10 tahun tanpa pengisian bahan bakar ulang $[8,9]$.

\section{METODE PENELITIAN}

Perhitungan sel bahan bakar menjadi langkah awal dalam mendesain teras reaktor. Sel bahan bakar terdiri dari tiga bagian yaitu fuel, cladding dan coolant [5]. Bagian bahan bakar (fuel) berperan dalam berlangsungnya reaksi fisi agar dapat menghasilkan panas yang diperlukan, bagian cladding merupakan material yang menentukan kekuatan struktur sel bahan bakar agar dapat menjamin tidak 
ada kebocoran selama reaksi fisi berlangsung, serta bagian coolant berupa pendingin berperan dalam mengantisipasi kelebihan panas yang dihasilkan dalam reaksi fisi.

Spesifikasi parameter desain sel reaktor disajikan pada Tabel 3.1. Reaktor terdiri dari beberapa komponen diantaranya sel bahan bakar, teras, sistem pendingin dan komponen reaktor lainnya.

Tabel 3.1 Spesifikasi Desain Parameter

\begin{tabular}{|c|c|}
\hline Parameter & Spesifikasi \\
\hline Fuel & $(\mathrm{Th}, \mathrm{Pu}) \mathrm{N}$ \\
\hline Material Cladding & Stainless Steel \\
\hline Material Coolant & Helium \\
\hline Geometri Cell & Cylindrical Cell \\
\hline Diameter pin pitch & 1,4 \\
\hline Pembagian & Fraksi Volume \\
\hline Fuel & $65 \%$ \\
\hline Cladding & $10 \%$ \\
\hline Coolant & $25 \%$ \\
\hline
\end{tabular}

Geometri sel bahan bakar yang digunakan pada perhitungan desain reaktor dalam penelitian ini yaitu bentuk silider (cylindrical cell). Penampang lintangnya disajikan seperti pada Gambar 3.1. [5].

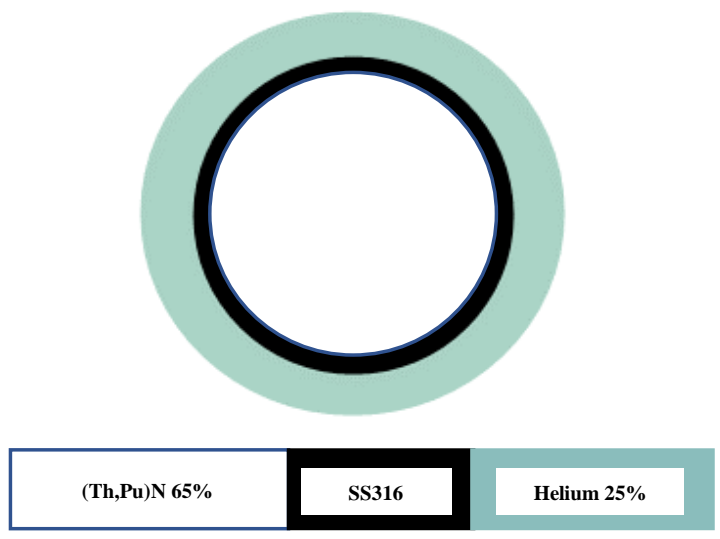

Gambar 3.1 Geometri Sel Bahan Bakar

Survey parameter untuk analisa hasil desain meliputi: $k$-effective sel bahan bakar, $k$-infinite, rasio konversi, dan distribusi densitas nuklida thorium-232, uranium-233, dan plutonium-239 selama 50 tahun waktu burnup bahan bakar.

\section{HASIL DAN PEMBAHASAN}

Perhitungan setiap komponen sel bahan bakar dilakukan dengan fitur PIJ pada paket program SRAC (Standard Reactor Analysis Code). Komposisi bahan bakar yang digunakan adalah campuran thorium plutonium nitrid. Penambahan persen konsentrasi plutonium dilakukan agar dapat memicu terjadinya reaksi fisi pada reaktor. Perhitungan ini menghasilkan beberapa survey parameter neutronik yaitu k-effective sel bahan bakar, k-infinite, rasio konversi distribusi densitas thorium-232, uranium-233, dan plutonium-239 yang disajikan kedalam gambar berikut. 


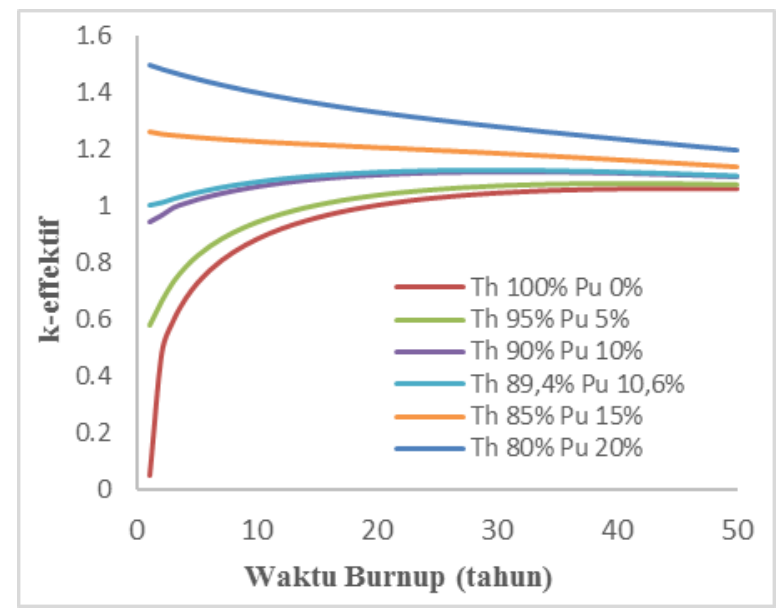

Gambar 4.1 Perubahan faktor multiplikasi efektif sel bahan bakar selama 50 tahun burnup

Gambar 4.1 menunjukkan nilai faktor multiplikasi efektif pada sel bahan bakar. Penggunaan bahan bakar thorium alam (100\% Th-232) menghasilkan nilai keff yang sangat rendah yaitu 0,05 di tahun pertama pembakaran kemudian meningkat dan baru mencapai 1,005 di tahun ke-18. Oleh karena itu, untuk meningkatkan performa tersebut perlu ditambahkan material fissile yaitu plutonium. Penambahan plutonium menghasilkan nilai keff yang lebih tinggi, sel bahan bakar mencapai kritis selama 50 tahun waktu burnup untuk penambahan 10,6\% plutonium dengan pembagian fraksi volume tetap yaitu $65 \%$ fuel, $10 \%$ cladding, dan $25 \%$ coolant.

Faktor multiplikasi tak hingga (kinf) menunjukkan kenaikan atau penurunan fluks neutron yang dihitung tanpa adanya faktor kebocoran ke luar teras dengan mengasumsikan ukuran sel bahan bakar tak hingga. Faktor multiplikasi tak hingga (kinf) ditunjukkan oleh Gambar 4.2. Nilai kinf sel bahan bakar mencapai 1 selama waktu burnup ketika bahan bakar ditambahkan plutonium sebesar $10 \%$. Kondisi ini cenderung mengalami penurunan selama burnup.

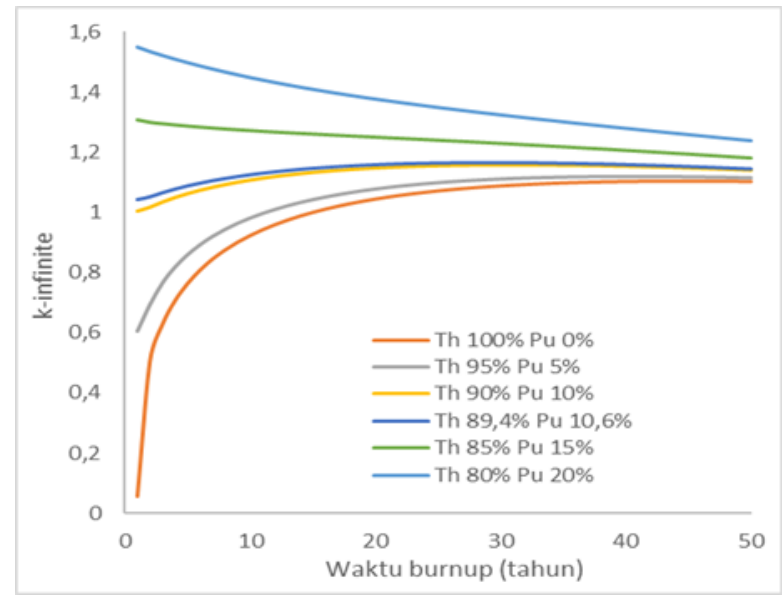

Gambar 4.2 Perubahan faktor multiplikasi infinite sel bahan bakar selama 50 tahun burnup

Selanjutnya, Gambar 4.3 menunjukkan parameter survey rasio konversi, yaitu jumlah bakan bakar fisil yang diproduksi berbanding bahan bakar fisil yang dikonsumsi. Untuk thorium murni, nilai rasio konversi pada tahun pertama bernilai 0 . Hal ini dikarenakan thorium-232 bersifat fertil. Nilai ini kemudian meningkat secara signifikan pada tahun pertama karena konsumsi uranium-233 sangat sedikit dibandingkan dengan uranium-233 yang dihasilkan pada rantai burnup thorium. 


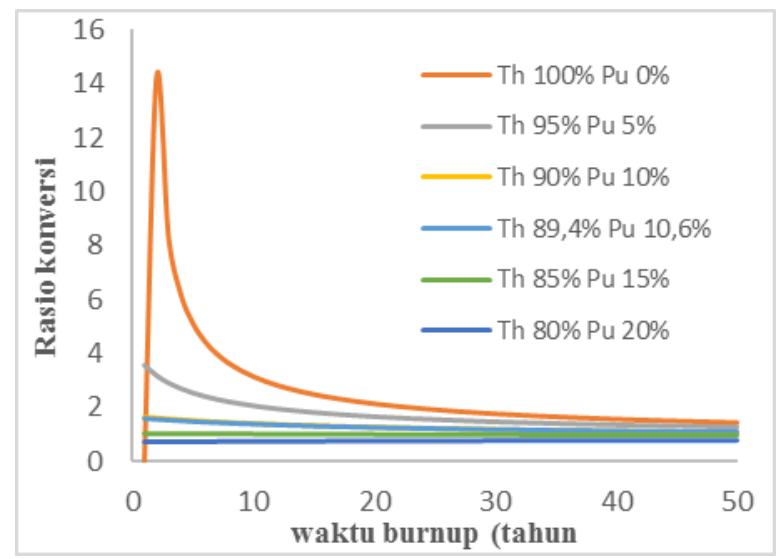

Gambar 4.3 Perubahan rasio konversi selama 50 tahun burnup

Perubahan densitas atom ditunjukkan pada Gambar 4.4, 4.5. dan Gambar 4.6. Pada Gambar 4.4 densitas thorium-232 seiring waktu burnup akan cenderung menurun karena thorium-232 dibakar dan mengalami reaksi fisi yang dipicu material fertile sehingga menghasilkan nuklida baru. Berdasarkan grafik terlihat bahwa densitas thorium menurun selama waktu burnup. Pada rantai burnup thorium232 menghasilkan uranium-233 yang densitasnya ditunjukkan pada Gambar 4.5. Berdasarkan gambar, densitas uranium-233 tertinggi dihasilkan pada persentase thorium 100\%. Penambahan persentase plutonium menyebabkan menurunnya densitas uranium-233.

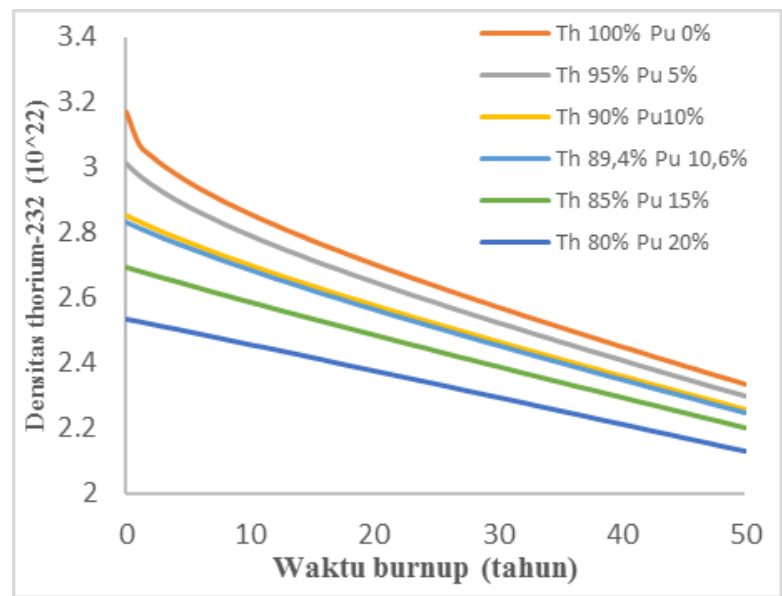

Gambar 4.4 Perubahan densitas thorium-232 selama 50 tahun waktu burnup

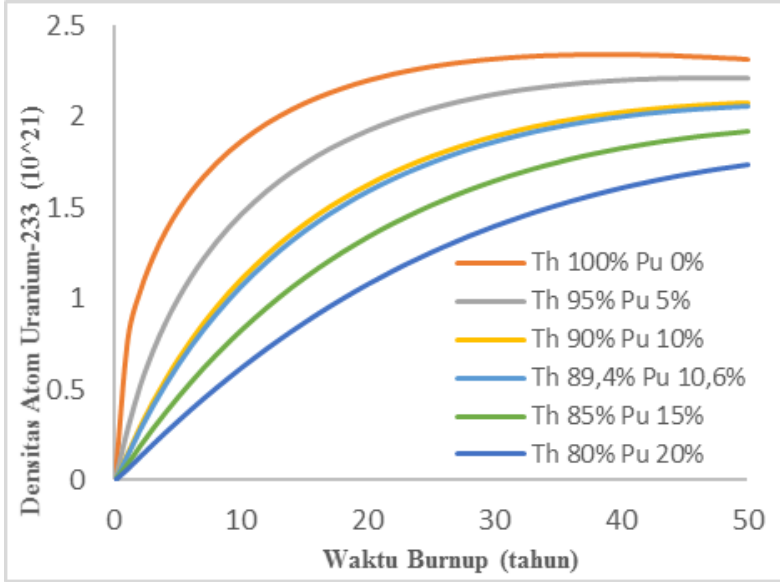

Gambar 4.5 Perubahan densitas uranium-233 selama 50 tahun waktu burnup 


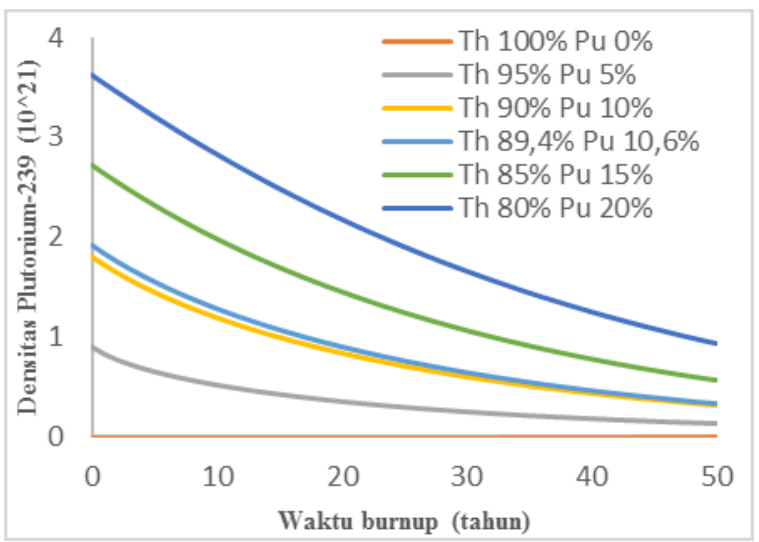

Gambar 4.6 Perubahan densitas plutonium-239 selama 50 tahun waktu burnup

Sedangkan densitas plutonium-239 ditunjukkan pada Gambar 4.6. Berdasarkan gambar, densitas plutonium tertinggi dihasilkan pada penambahan plutonium sebanyak $20 \%$, semakin sedikit persentase penambahan plutonium maka densitas plutonium selama burnup juga semakin sedikit.

\section{SIMPULAN}

Studi parameter burnup sel bahan bakar pada reaktor cepat berpendingin helium telah dilakukan. Untuk fraksi volume $65 \%$ fuel, $10 \%$ cladding, dan $25 \%$ coolant, sel bahan bakar thorium plutonium nitride dengan persentase plutonium sebanyak 10,6\% menghasilkan keadaan kritis dengan keff $=1$, 004 ditahun pertama burnup, dan menghasilkan rasio konversi yang nilainya cenderung menurun antara 1,55 hingga 1,08 selama 50 tahun burnup.

\section{REFERENSI}

[1] Duderstadt, J., dan Hamilton. 1976. Nuclear Reactor Analysis. New York: John Wiley \& Sons.

[2] Dewita, E. 2012. Analisis Potensi Thorium Sebagai Bahan Bakar Nuklir Alternatif PLTN. Jurnal Pengembangan Energi Nuklir Vol14(1), hal.45-56.

[3] IAEA. 2014. International Status and Prospects for Nuclear Power 2014. Technical Report. International Atomic Energy Agency.

[4] Kidd, S.W. 2009. Nuclear Fuel Resources. CRC Press. New York

[5] Okumura, Keisuke. 2007. Introduction of SRAC for Reactor Physics Analyses. Japan: JAEA.

[6] World Nuclear, 2012. Tersedia di: http://www.world-nuclear.org/, diakses tanggal 04/02/2017/19:45

[7] Ragheb, M. 2011. Thorium Fission-Fussion Fuel Cycle. Journal of Nuclear PowerDeployment, Operation and Sustainability. DOI: 10.5772/18985.

[8] Ariani, M., Z. Su'ud, Waris, A., Khairurrijal, dan F. Monado. 2012. The Feasibility Study of Small Long-Life Gas Cooled Fast Reactor with Mixed Natural Uranium/Thorium as Fuel Cycle Input. AIP Conference Proceeding Vol.1448, hal.59-64.

[9] Ariani, M., F. Monado., Supardi., Z.Su'ud. 2015. Potensi Thorium Sebagai Bahan Bakar Pada Reaktor Cepat Berpendingin Gas Untuk PLTN. Prosiding SEMIRATA 2015 , hal 39-45. Universitas Tanjung Pura. 